\title{
Improving The Student Learning Outcomes Through Public Relation Administration Module Development Based on POE Protocol
}

\author{
Yurikhe Indah Ayuning Puspa \\ Lulu Nurul Istanti \\ Program Studi Pendidikan Administrasi Perkantoran Universitas Negeri Malang \\ Imam Muchayat \\ SMK Negeri 1 Malang \\ Email: lulu.nurul.istanti.fe@um.ac.id
}

\begin{abstract}
The purpose of this research is to produce module of Public Relation and Protocol Administration based on POE for Eleventh Grade Office Administration 2 which has been tested its validity and to know the improvement of student learning outcomes after using this module. This type of research is research and development with using Borg \& Gall model. Research indicates that the module of Public Relations and Protocol Administration using POE model have been validated and the result is feasible to be used and the student's learning outcomes in the experimental class are higher than the control class.
\end{abstract}

Keywords: module, POE, public relation and protocol, learning outcomes

Human and education have a close relationship and their exsintance can not be separated because education is used to meet the needs of human life. According to Tirtarahardja (2005: 153) education plays an important role in preparing students to play a role in the future. Education is the main factor and pillars to anticipate the future. Education will lead to changes the knowledge and behavior of learners to be better. The main purpose of education is to educate the life of the nation. Based on this goal the government seeks to improve the quality of education by implementing some curriculum in Indonesia. Especially in this year, the government has implemented the latest curriculum (2013 Curriculum) as an effort to improve the quality of education. Kibirige (2014: 300) says that the curriculum is developed to uphold the constitutional and democratic values that deserve to provide the education quality.

The 2013 Curriculum has been officially implemented in the 2013/2014 academic year in July 2013. According to Fadlillah (2014: 16), the 2013 Curriculum is a development from previous curriculum which is including the prior-thematicintegrative characteristics and has a purpose to improve and balancing the soft skill and hard skills the form of attitude such as skill and knowledge of learners by adding hours of study. Since the 2013 Curriculum has been implemented, the 2013 Curriculum has reaped many problems. According to Muljati in Daily Sinar Harapan (2014), Sekjen Federasi Serikat Guru Indonesia (FSGI) Retno Listyarti said that the issue of 2013 Curriculum is not only limited to teachers' unpreparedness, the delay of books arriving at school also causes problems for teachers. The delay package of the 2013 Curriculum for students and teachers can cause teachers to have less time to develop Rencana Pelaksanaan Pembelajaran (RPP) before organizing the learning 
process. This is inversely proportional to the opinions expressed by Hidayat (2013: 158) that the success of the implementation of the 2013 curriculum apart from educators and education, the success of the implementation of Curriculum 2013 is also supported by the availability of books or teaching materials as a source of learning.

Based on the interviews results that have been conducted with Mr. Imam Muchayat,. S.Sos researcher correspondent teacher of Public Relations and Administration Protocol on October 2, 2016 in SMKN 1 Malang. He found that the teacher have not enough teaching materials that will be used for teaching and learning process. Teachers only cite and retrieve the material in internet articles whose material is in accordance with the subjects taught. Similarly, when assigning tasks, teachers only provide direction to students to find material on the internet. From the results of this interview found that the results of student XI APK class who learning on the subjects of Public Relations and Protocols Administration only amounted to 62.5 . From the data, it can be seen that the students' learning outcomes do not meet the Kriteria Ketuntasan Minimal (KKM) that is 75 and students are also less motivated in learning. This is happen because the learning difficulties faced by students and the lack of teaching materials on the Subject of Public Relations and Protocol Administration. This is inversely proportional to the success of the teaching and learning process in schools, the success of teaching and learning in schools need to be supported by one important factor that is the teaching materials that become a reference for teachers and students in the learning process.

Based on the above problems, researchers want to develop a teaching material in the form of modules. The module is a form of teaching material that is structured as a whole and systematic, in which consists of a set of planned learning experience and is designed to help learners master the learning objectives (Daryanto, 2013: 9). Majid (2012: 176) describes the module is book for helping the teaching material written and organized with the aim that learners can learn independently without or with teacher guidance. Implementation of modules needs to be done to achieve the learning objectives and standards of competence that have been set. The module serves as a learning tool for students who are independent, so that students can learn independently with the speed they have each.

Administration Office subject is one of the existing skills program at SMKN 1 Malang which there are subjects of Public Relations and Protocol Administration. In the presentation of the subjects, there is Kompetensi Dasar (KD) Systematics Writing Meeting Report which discusses the steps - steps in writing report of the meeting after the meeting was held. The module is basic competence systematics writing the report of the meeting can be used as a provider of basic information so that it can be a material to practice for learners.

Achievement of competence or learning goals is strongly influenced by teachers. In order to improve students 'ability to learn independently in the learning process, teachers need to arouse students' desire to investigate something. So, researchers use the model of learning POE (Predict, Observe, Explain) because it is felt

right in writing this learning module. According to Warsono (2016: 93), the model of learning POE (Predict, Observe, Explain) is a learning model that aims to reveal and explore students' ability in doing individual predictions. This opinion is in line 
with the opinions of Kose, Costu \& Keser (in Şeșen, 2016: 186) stating that POE is used to give students an opportunity to predict the outcome of the situation on the grounds and also to ensure students observe the situation and make explanations to remove conflicts between predictions and observations .

The involvement of students in the learning process begins with the curiosity of the students themselves. Teachers can raise the curiosity of students by giving a problem so that it will cause a desire from students to solve problems by using facts that are then observed, so that will improve students' logical thinking ability. POE learning model (Predict, Observe, Explain) can be used to explore the initial knowledge of the students so as to provide information to the teacher about students' thinking ability. When teachers begin to be able to recognize students 'skills, teachers will be able to condition students to conduct discussions and motivate students to explore the concepts they have so as to arouse students' desire to investigate. Thus, this learning model is effective to improve student learning outcomes. Learning outcomes are the outcomes that students achieve in the form of numbers or scores after the teacher gives the learning result test at the end of each lesson. The value obtained by these students will then be used as a reference to see the mastery of students in receiving learning materials (Dimyati, 2006: 200).

The theories that have been described above need to be supported by previous research conducted by Widyaningrum et al (2014) entitled "Development of POE Module (Predict, Observe, Explain) on Pollution Material to Improve Student Learning Results". The result of the research was done with the learning strategy of POE (Predict, Observe, Explain), that is the feasibility of learning module developed get 3.3 value after field test and categorized "Good" with achievement of student learning result have significant improvement in "Middle" category.

Further research was also conducted by Suleman et al (2015) entitled "The Effect of Learning Strategy with POE Technique on Learning Outcomes Concept of Electrolyte and Nonelectrolyte Solution Students in Class X SMA Negeri 1 Kabila". The result of research done by using the learning strategy of POE (Predict, Observe, Explain) it can improve student learning outcomes with the average of students' learning outcomes in the experimental class and the classes using POE learning (Predict, Observe, Explain) is 17.58 and flat - average learning outcomes in the control class ie classes that do not use learning POE (Predict, Observe, Explain) is 17.17 ".

\section{METHOD}

This research used the research and development method, using the module development procedure uses the Borg \& Gall model developed by Gall \& Borg. In this study the researchers modify the research and development model proposed by Borg \& Gall into 8 steps due to limited time, effort and cost. The research and development steps of the modified result are: 1) Potential and problem, 2) Data collection, 3) Product design, 4) Design validation, 5) Design revision, 6) Product trial, 7) Product revision, and 8) Usage test.

The first stage of this research is to analyze potentials and problems. At this stage the researcher conducted an interview to one of the teachers of Subject of Public Relation and Protocol Administration in SMKN 1 Malang, from the interview 
result it was found that the teacher did not have enough teaching materials that will be used to perform the teaching and learning process because of many subjects and materials New as the impact of the implementation of the latest curriculum that is 2013 Curriculum, so the teacher just quotes and takes the material in internet articles that the material in accordance with the subjects taught. From the results of this interview also found that the results of student learning class XI APK on the subjects of Public Relation and Protocol Administration only 62.5. From the data can be seen that the results of student learning does not meet the Kriteria Ketuntasan Minimal (KKM) is 75 and students are also less motivated in learning. Furthermore, at the data collection stage the researcher conducted observation in SMKN 1 Malang to know the characteristics, abilities, modules used and student learning outcomes on subjects of Public Relations and Protocol Administration as material for data collection. The softcopy module used in this research for students of Class XI APK 2 in SMKN 1 Malang is source from internet search results.

At the product design stage, the researcher designed the learning module according to product specification that will be developed by analyzing syllabus of Public Relations and Protocol Administration in SMKN 1 Malang to determine the material that will be used in developing the module. This analysis is done by identifying the main material needed, reviewing sub-topics, determining the tasks of learners such as individual and group tasks and organizing them systematically in the form of concept maps based on learning objectives. Furthermore the product will be validated by the material expert Mr. Imam Muchayat, S. Sos who will assess the module of content feasibility aspects, feasibility of presentation and effectiveness of the use of modules. As for the expert module will be done by Mr. Drs. H. Mohammad Arief, M.Si who will assess the module of language feasibility aspects, feasibility of presentation and feasibility of kegrafikan. Once the product design is validated by the material expert and module expert, the criticism and suggestions provided will be used by the researcher as a reference for revising or improving the product developed by the researcher for the better.

After the product was validated and revised, the results of the revised module were tested to a small group of class XI APK 1 consisting of 6 students, each consisting of 2 high ability students, 2 medium ability students, and 2 students of low ability as user Modules and researchers prepare assessment instruments.Based on the results of small group validation if still found deficiencies, then the product of development will be revised. After the product has been validated and revised, the results of the revised module are tested to a large group consisting of experimental class and control class. The experimental class is the class where the experimenter performs the experiment using POE (Predict, Observe, Explain) module ie class XI APK 2, while the control class is a class that does not use the module but only by using the learning method of POE (Predict, Observe, Explain) Namely class XI APK 4. Then do posttest to know the student learning outcomes of each class.

The data obtained in the development of this module is quantitative qualitative data. Qualitative data is obtained from the notes, comments, criticisms, or suggestions provided by the validator used for module repair or revision. While the quantitative data obtained from the assessment questionnaire of trials and data 
from posttest results. The data collected through the series of evaluations are data from module expert test, material expert test, small group trial and large group test.

Instruments used as data collection on the development of this module are questionnaires, tests and interviews. In the questionnaire, the study was used to collect the data in the form of assessment based on BSNP and data on the quality of product feasibility. Data obtained from questionnaire is quantitative and qualitative data. The measurement scale in the questionnaire uses Likert scale, which consists of 4 categories (Sugiyono, 2013: 134-135):

Validation results are then analyzed by using the following formula:

Information:

$$
=\frac{\sum x}{\sum x i} \times 100 \%
$$

: Average value (in percent)

$\Sigma$ : Number of Respondents Score

$\Sigma$ : Total Score Answers

100\%: Constants

(Source: Suparti, 2016: 192)

The conclusion of percentage analysis above, can be known by developing the level of validity criteria. Table 1 below shows the classification of levels of validation criteria.

Table 1. Validity Criteria for Validation Data Analysis

\begin{tabular}{cl}
\hline Percentage & \multicolumn{1}{c}{ Information } \\
\hline $81 \%-100 \%$ & Very valid (can be used without revision) \\
\hline $61 \%-80 \%$ & Valid (can be used but needs to be revised small) \\
\hline $41 \%-60 \%$ & $\begin{array}{l}\text { Neither (recommended not used because of major } \\
\text { revisions required) }\end{array}$ \\
\hline $21 \%-40 \%$ & Invalid (may not be used) \\
\hline $0 \%-20 \%$ & Very invalid (should not be used) \\
\hline
\end{tabular}

Source: Akbar, 2013: 42

In the test result analysis, experimental class and control class learning differences were analyzed using posttest. The two outcomes of each treatment were compared using the mean of the class to determine whether or not there was an increase in student learning outcomes. If the experimental class learning outcomes are higher than the control class learning outcomes, then learning by using the POE (Predict, Observe, Explain) PRE and POE Protocol Based Administration module in the Systematic Material of Writing the Meeting Report is more effective.

The interviews conducted to teachers of subjects of Public Relation and Protocol Administration are used to identify the initial needs up to the final product stage of module development concerning the Systematics of POE (Predict, Observe, Explain). 


\section{RESULTS \& DISCUSSION}

\section{Results}

Based on the validation results of the material experts, module and student experts obtained the result that the POE Administration-based Public Relations and Protocol module is feasible to be used, the following is presented the results of product development developed by the researcher.

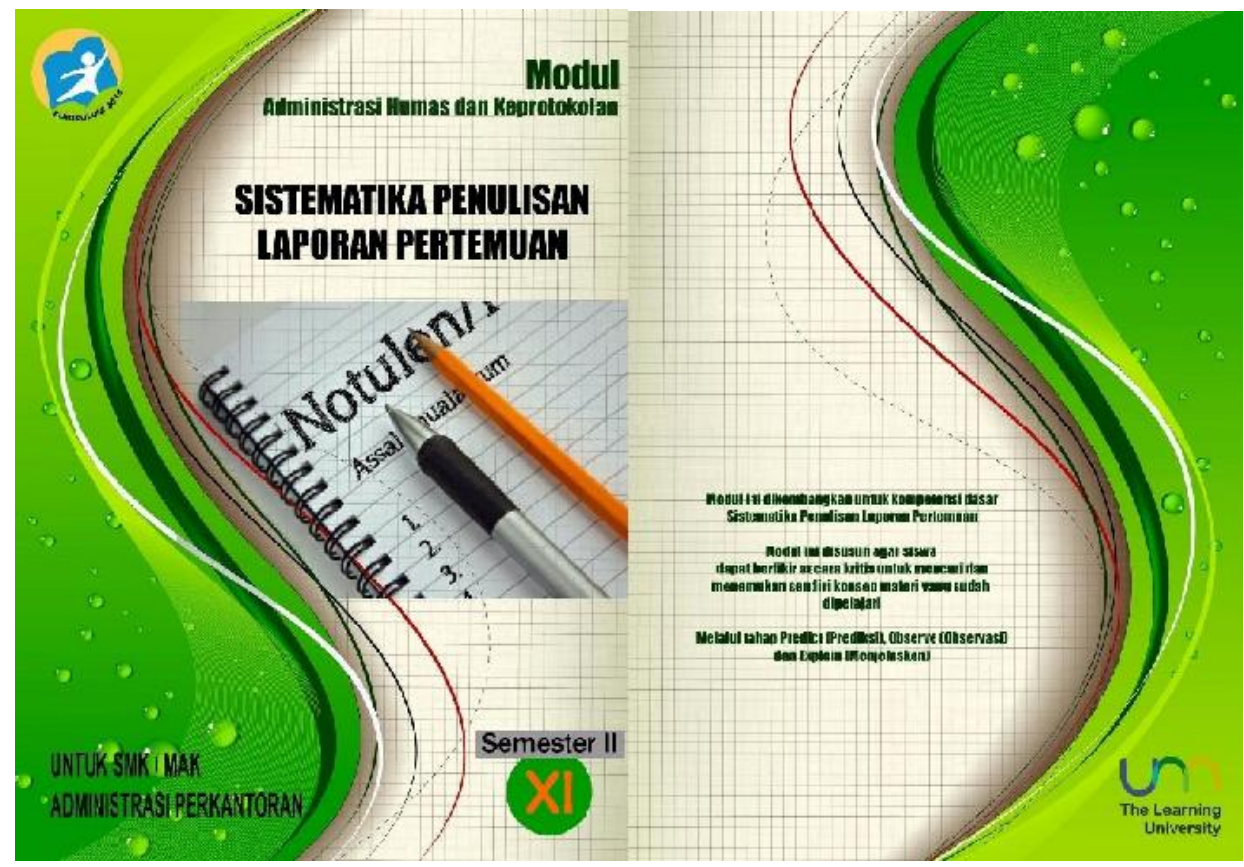

Figure 1. Front and back cover modules

The validation results of the material experts, module experts and students for POE (Predict, Observe, Explain) PRE and POE Protocol are divided into 2 types of data, namely quantitative and qualitative data. The results of quantitative data on product validation obtained from material experts are shown in Table 2 below.

Tabe 12. Quantitative Data of Validation Expert Content

\begin{tabular}{rlllll}
\cline { 2 - 5 } No. & Rated aspect & $\Sigma \mathrm{x}$ & $\Sigma \mathrm{xi}$ & $\%$ & Information \\
\hline 1. & Feasibility of content & 33 & 36 & 91.7 & Very valid \\
\hline 2. & $\begin{array}{l}\text { Feasibility of } \\
\text { presentation }\end{array}$ & 29 & 32 & 90.6 & Very valid \\
\hline 3. & $\begin{array}{l}\text { Effectiveness of } \\
\text { module usage }\end{array}$ & 11 & 12 & 91.7 & Very valid \\
\hline & AMOUNT & 73 & 80 & 91.3 & Very valid \\
\hline
\end{tabular}

(Source: Quantitative Data from Expert Content Validation, 2017)

Table 2 shows the data acquisition of expert material questionnaires of 91.3\% which means POE (Predict, Observe, Explain) PROPER and PROPER PROCESS 
module in the Systematic Material of Generated Report Writing which has a criterion is very valid or feasible to use. As for the qualitative data obtained from the criticism and suggestions provided by the material experts can be seen in Table 3 .

\section{Table 3. Product Validation Notes or Suggestions from Experts of Materials}

\begin{tabular}{ll}
\hline Suggestion & Recommendation \\
\hline Modules are made more interesting to read students & \\
The frame in the module is reduced & Proper to use \\
Use the default font size of 11 or 12 &
\end{tabular}

(Source: Data Validation Result of Expert Material Questionnaire, 2017)

Based on Table 3 there are suggestions and notes from the material experts regarding the aspect of the feasibility of module kegrafikan. All suggestions and notes from the material experts in the revision phase of product design become the reference materials to make improvements and refine the contents of the module.

The results of quantitative data on product validation obtained from module experts are shown in Table 4 below :

Tabe 1 4. Quantitative Data of Valiidation Expert Module

\begin{tabular}{|c|l|c|c|c|l|}
\hline No. & \multicolumn{1}{|c|}{ Aspects assessed } & $\sum \mathrm{x}$ & $\sum \mathrm{xi}$ & $\%$ & Information \\
\hline 1. & Feasibility Language & 32 & 32 & 100 & Very valid \\
\hline 2. & Feasibility of Presentation & 23 & 24 & 95.8 & Very valid \\
\hline 3. & Feasibility of graduation & 21 & 24 & 87.5 & Very valid \\
\hline & AMOUNT & 76 & 80 & 95 & Very valid \\
\hline
\end{tabular}

(Source: Quantitative Data of Expert Module Validation Result, 2017)

Table 4 shows the acquisition of data from a module expert questionnaire that is 95\%, which means POE (Predict, Observe, Explain) PRA and POE Administration Module on the Systematic Material of Generated Report Writing has a criterion that is very valid or feasible to use. As for the qualitative data obtained from the criticism and suggestions provided by the material experts can be seen in Table 5.

Table 5. Product Validation Notes or Suggestions from Expert Module

Suggestion Recommendation

The color composition on the module cover is improved Very feasibility for use

(Source: Data Validation Result of Expert Messaging Module Product, 2017)

Based on Table 5 there are suggestions and notes from module experts regarding the aspect of the feasibility of graphic module. All suggestions and notes from the module expert in the revision phase of product design become the reference material to make improvements and refine the contents of the module. 
The results of quantitative data on product validation obtained from students or small groups conducted by 6 students of grade XI APK 1 are shown in Table 6 below.

Table 6. Data on Small Group Test Results

\begin{tabular}{cccccc}
\hline No. & $\begin{array}{c}\text { Student } \\
\text { Name }\end{array}$ & $\boldsymbol{\Sigma} \mathbf{x}$ & $\boldsymbol{\Sigma} \mathbf{x i}$ & $\mathbf{\%}$ & Information \\
\hline 1. & Student 1 & 36 & 40 & 90 & Very valid \\
\hline 2. & Student 2 & 30 & 40 & 75 & Valid \\
\hline 3. & Student 3 & 34 & 40 & 85 & Very valid \\
\hline 4. & Student 4 & 31 & 40 & 77.5 & Valid \\
\hline 5. & Student 5 & 37 & 40 & 92.5 & Very valid \\
\hline 6. & Student 6 & 31 & 40 & 77.5 & Valid \\
\hline & Total & 199 & 240 & 82.9 & Very valid \\
\hline
\end{tabular}

(Source: Data Result of Student Question Validation Product, 2017)

Table 6 shows the data from survey or small groups is as much as $82,9 \%$ which means the Public Relation and Administration Protocol module based poe (predict observe , explain) to the matter systematic of writing reports of the meetings produced possesses the criteria perfectly valid or being used .Meanwhile for data qualitative obtained from criticism and advice provided by the material .

Suggestions and notes from students regarding the aspect of feasibility of graphic module. All suggestions and notes from the module expert in the revision phase of product design become the reference material to make improvements and refine the contents of the module. The trial usage in this research was conducted to know the difference of learning result between the experimental class and the control class after using the POE (PRedict, Observe, Explain) Public Administration and PR protocol module. The comparison of learning outcomes is seen from the average of learning outcomes in the experimental class and the controls obtained from the student's posttest score.

The trial usage is carried out in class XI APK 2 which is a class using POEbased Public Relation and Administration Protocol module which is 31 students with 4 meetings. Then class XI APK 4 is a class that does not use the module but only use POE based learning method that amounted to 32 students with 3 meetings. At the last meeting in each class, the researcher conducted a posttest to know the difference of the students' learning outcomes in the experimental class and the control class which then the result of the posttest was processed and compared to each class. The posttest result of the experimental class and control class is as follows. 
Table 7. Posttest Result of Experiment Class and Control Class

\begin{tabular}{lccccc}
\hline No. & Class & $\begin{array}{c}\text { The number } \\
\text { of students }\end{array}$ & verage value & $\begin{array}{c}\text { Number of } \\
\text { Students } \\
\text { Finished }\end{array}$ & $\begin{array}{c}\text { Number of } \\
\text { Unfinished } \\
\text { Students }\end{array}$ \\
\hline 1. & XI APK 2 & 31 students & 84 & 25 & 5 \\
\hline 2. & XI APK 4 & 32 students & 71.1 & 11 & 20 \\
\hline
\end{tabular}

(Source: Data processed by Researcher)

Table 8 shows that the posttest result of the students in the experimental class is higher than the control class and the total number of students completed in the experimental class is higher than the control class so it can be concluded that learning by using POE (Predict, Observe, Explain) More effectively used in teaching and learning process.

\section{Discussion}

The product of the development result in this research is in the form of teaching materials in printed form, ie learning module of Public Relations and Administration Protocol on the Systematics of Writing of Meeting Report by using learning strategy of POE (Predict, Observe, Explain) equipped with teacher handbook. In the teacher handbook contains the material and also the exercise of the same problem with the student module, only in the teacher manual is also equipped with Rencana Pelaksanaan Pembelajaran (RPP), key answers and assessments that teachers can use as a reference to assess the exercise questions on the module Students.

POE learning model is a learning model based on the theory of constructive. According to Widyaningrum (2014: 99) models of POE is a series of problem-solving process performed by the students through the prediction stage or make a first approximation, observation or demonstration, and explanation for the observations. This opinion is in line with the opinion of Kibirage, Osodo, Tlala, (2014: 301) that the total student participation in the lesson using the POE model includes 3 characteristics of prediction, observation and explanation.

Steps of learning POE (Predict, Observe, Explain) used as a stage of the use of development module is predict, observe and explain, then the learning steps are implemented in a module that includes three parts Let's predict, at this stage the student will be divided into several small groups and the teacher gives a problem by presenting a picture of the notes to be observed and predicted by the student. Then ask the student questions with the picture like "What do you think the note type is? Also explain your reasons". Is the note already in conformity with the composition of the meeting report or notula? Explain your reasons! ". The student will then answer the question in the module. As the research conducted by Nana (2014: 58) at the predictor stage gives teachers a problem to predict by students, students will answer questions by making excuses why they predict as such, teachers also give students the freedom to pour their ideas and concepts.

"Let's observe", at this stage students perform activities or demonstrations to find answers and prove the results of their predictions about the problems that have been given by teachers at the predict stage. As the opinion has been put 
forward by (Şeșen, 2016: 186) that at the observation stage, students can see whether one of their predictions is right or wrong (Hilario, 2015: 39).

"Let's explain", at this stage the teacher provides an opportunity for the students to deliver the results of the experiments and observations he gets in front of the class. This stage can be done by drawing group numbers to present the results of the discussion in front of the class. This strategy is applied by teachers with the aim that each group should prepare so that all groups are involved during the learning process. For groups who do not have the opportunity to present the outcome of the discussion, the teacher will ask whether the essence of the discussion results is the same as the other group, if not the same then the group is given the opportunity to give an opinion or suggestion.

Based on the module validation results conducted by the material experts, module experts, and students, that module developed by the researcher included in the criterion is very valid and very suitable to be used as teaching material for the class XI student of Office Administration Study Program. The level of feasibility of the module that has been developed includes five aspects. The fifth aspect is the content feasibility aspects, feasibility aspects of presentation, language feasibility aspects, aspects of feasibility kegrafikan and aspects of the effectiveness of the use of modules.

In the content feasibility aspect, the product of the development of this learning module uses the POE model (Predict, Observe, Explain) consisting of one basic competence that is Explain the Systematics of Writing Meeting Report which then developed in some indicators and step of learning POE (Predict, Observe, Explain ) So it becomes 2 learning activities that must be achieved by students. In Learning Activity 1, students will learn about systematic writing of meeting report, while in Learning Activity 2, students will learn how to make meeting report. The material presented in the module is adapted to the syllabus of Public Relations and Protocol Subject which is arranged systematically so that all the indicators and learning objectives can be achieved. The module also comes with practice questions at the end of each learning activity so that it can train students' understanding of the material they have learned. The training provided is designed using the cognitive and psychomotor aspects, so that students' knowledge and practice are balanced.

In the aspect of feasibility of module presentation is presented with attention to the demands and completeness of the presentation. The material in the module is presented coherently by referring to the learning stages of POE (Predict, Observe, Explain) which start from the prediction to explain and arranged according to the order in the syllabus. Completed presentation module consists of 3 main parts namely introduction, content and cover. The introductory section of the module consists of cover, introduction, table of contents, learning flow, introduction (background, prerequisites, core and basic competencies, learning objectives and module usage instructions) and concept maps. Then the contents of the module consist of the title page of the learning activity, let's read, let's predict, let's observe, let's explain, summaries, independent assignments, group assignments, evaluation questions, competence tests and notes. While the cover consists of follow-up, glossary, bibliography, and author biography.

In the language feasibility aspect, the language used in the module is adapted to Indonesian language rules written with grammar, spelling, sentence structure 
and correct use of sentences so that students are able to understand the messages contained in the module. Language is presented scientifically but not rigidly and adapted to students' thinking ability so that students are easy to learn modules. Languages not familiar to students are listed in the glossary. The glossary in this module serves to define a scientific language that is not understood by students.

Graphic aspects of this module include: (a) cover design, (b) layout, (c) illustrations or drawings, and (d) typography. The front cover design is designed by displaying the Notula image so it can illustrate the contents of the module. Front and rear covers are designed using a combination of green and white base colors. In addition, the module is also printed using A4 paper in accordance with ISO standards.

The module layout includes the suitability of the placement elements of the module sections. Module printed with upper, lower and right border $3 \mathrm{~cm}$ while left border $4 \mathrm{~cm}$. The title is placed at the top and in bold. The module also comes with illustrations or images that correspond to the material and is useful for supporting the presentation of the material. The module also completed with motivation sentences for improving the student learning motivation.

Typography includes the size and typeface and color selection. Common letters used in the module are Times New Roman with 12 pt size and the dominant color selection in 4 colors are orange, blue, pink and green. The size and type of letters used are combined in accordance with the requirements for easy user readability.

Aspects of the effectiveness of the use of modules that are validated by the material experts include the development of students 'desire to dig deeper information, students' ability to think critically and student learning independence. Modules are developed using the problems that occur in everyday life by making the questions at the POE stage further explore students' ability in formulating hypotheses so that students will be more able to think critically. If the ability of students already excavated then automatically the independence of student learning will appear so that teachers only act as a facilitator because students are motivated to learn independently.

Research and development of this module aims to improve student learning outcomes. This module is tested to class XI APK 2 to know the difference of student learning result between experiment class and control class after using module. Measurements of student learning outcomes were analyzed using students' posttest scores. Based on the result of learning obtained by student indicate that student's learning result in experiment class is higher than control class so it can be concluded that learning by using POE (Predict, Observe, Explain) PRE and POE protocol based module is more effective to be used in learning process. Improvement of student learning outcomes is more dominant occur in the observe stage because at this stage students will find answers from predictions through an activity or demonstration, where at this stage students will be more open insights. This is because the stages of the module are presented systematically and the questions at POE stage are made by involving cognitive and psychomotor aspects so that students can think critically.

The results of this study are also supported by previous research conducted by Widyaningrum et al (2014) which shows that the development of modules is 
feasible to be used in the learning process and can improve student learning outcomes. This can be seen from the validation results of experts and practitioners who showed that the module developed scored 3.3 of the "Good" category and the average achievement of student learning outcomes at posttest (81.44) was higher than the pretest score $(61,41)$. The results of this study also supported by previous research conducted by Rahayu et al (2013) which shows that the module developed valid and average student learning outcomes at the time of pretest only 57 with a mastery of $11.43 \%$ and then at posttest increased by 82 With $97 \%$ completeness.

Based on the previously described product review, this POE-based POE Administration and Public Relations Administration module has several advantages: (1) the module is developed using the POE basis so that the students are more active by interacting with teachers and peers by revealing and exploring students' knowledge and Actively encouraging students to engage in learning, (2) modules organized systematically by giving color and also motivational words that make the module more interesting so that students are more interested and motivated to learn, (3) the use of illustrations or images according to the material (4) the module is equipped with training questions that students can use to train and measure students' understanding, (5) the module can train students to learn independently so that students are not dependent on the teacher, and (6) the module Developed through a revision process and tested Validation so as to produce a decent product for use in teaching and learning.

There are several obstacles experienced by the researcher during the module usage test that is (1) the module developed contains only one basic competence that is systematic writing of meeting report so that the researcher difficulties to develop the material and also make the student assignment, and (2) the student is not accustomed to using the learning model Based on POE so teachers need to provide explanations and guidance on POE-based learning models before the learning process begins.

\section{CONCLUSION \& SUGGESTIONS}

\section{Conclusion}

Based on studies of the products developed by the researchers, there are some conclusions that are outlined as follows: (1) based on the results of the validation of the product by experts of expert modules and materials, students that modules that were developed included within the category of very valid, so the modules developed by researcher worthy of use in teaching and learning activities in the classroom, and (2) Module developed by researchers can enhance student learning outcomes, this can be seen from the median value of the mean posttest results - students learn that the results of the experiment class higher than the class of the control.

\section{Suggestion}

Based on the trial results, the results of the development of the modules developed by researchers had been valid and feasible to use. However the module that was 
developed there are still some shortcomings. Weaknesses - the weakness contained in the module then generates suggestions for further utilization. The suggestions are: (1) Suggestion of utilization, (a) suggestions for teacher is should advised to use Public Relations and Administration Protocol modules based on POE (Predict, Observe, Explain) in classroom learning activities. It is because the module can develop students 'thinking ability by revealing and exploring students' knowledge so that students can play an active role by interacting with teachers and peers. This module has also been proven to improve student learning outcomes. In addition, teachers will be helpful in delivering learning materials and teachers no longer need to dominate the activities of students in the classroom because students can learn independently using the module. Teachers only act as facilitators who guide students in finding concepts, therefore teachers are expected to deepen the material presented in the module.

In addition to deepening the material presented in the module, teachers should also combine it with supporting media to make it easier for students to understand the material, and (b) suggestions for students, students are advised to know the concept map in learning activities by learning it first before the implementation of learning activities in the classroom. It is intended that students are better prepared and have sufficient insight during the learning process takes place. Students can also participate in all POE learning stages and work on the questions presented in the module to train and measure students' abilities. Students are not allowed to continue the next learning activity before they can master the stage contained in the module well. If there are still things that have not been understood by the students, students can ask the relevant subject teachers because students are required to be active in the learning process in the classroom. (2) Suggestion of dissemination, the product developed by this researcher can be disseminated to the subject teacher of Public Relation and Administration Protocol at SMKN 1 Malang. The product of this development result can also be disseminated through the Musyawarah Guru Mata Pelajaran (MGMP) for dissemination to teachers who teach the same subjects. Thus, the module can be recognized by the wider community and can be utilized for the sustainability of the learning process. (3) Further product development suggestions, based on the results of product trials conducted by the researchers, are expected to develop the next product to do the following: (a) Developing the material of Systematic Writing Report The meetings in the module should be further developed so that the scope of the material is wider with add the recent drawings, (b) Module development should be done on other subjects or on other basic competencies in addition to the Systematics of Writing the Meeting Report.

\section{REFERENCES}

Akbar, S. 2013. Instrumen Perangkat Pembelajaran. Bandung: PT Remaja Rosdakarya Offset.

Daryanto. 2013. Menyusun Modul: Bahan Ajar untuk Persiapan Guru dalam Mengajar. Yogyakarta: Gava Media.

Dimyati., Mudjiono. 2006. Belajar dan Pembelajaran. Jakarta: Rineka Cipta. 
Fadlillah, M. 2014. Implementasi Kurikulum 2013 dalam Pembelajaran SD/MI, SMP/MTS, \& SMA/MA. Yogyakarta: Ar-Ruzz Media.

Hidayat, S. 2013. Pengembangan Kurikulum Baru. Bandung: PT Remaja Rosdakarya Offset.

Hilario, J., S. (2015). The Use of Predict-Observe-Explain-Explore (POEE) as a New Teaching Strategy in General Chemistry-Laboratory. International Journal of Education and Research, 3 (2): 37-48.

Kibirige, I., Osodo, J., Tlala, K.M. 2014. The Effect of Predict-Observe-Explain Strategy on Learnes Misconceptions about Dissolved Salts. Mediterranean Journal of Social Sciences. (Online). 5(4): 300-310. (www.mcser.org), diakses tanggal 6 November 2016.

Majid, A. 2012. Perencanaan Pembelajaran: Mengembangkan Standar Kompetensi Guru. Bandung: Remaja Rosdakarya.

Muljati. 2014. Masalah Kurikulum 2013 Bukan Hanya Guru. (Online). (http://sinarharapan.co/news/read/140806114/masalahkurikulum-2013bukan-hanya-guru-span-span-), diakses tanggal 5 Februari 2015.

Nana., Sajidan., Akhyar, M., Rochsantiningsih, D. 2014. The Development of Predict, Observe, Explain, Elaborate, Write and Evaluate (Poe2we) Learning Model in Physics Learning at Senior Secondary School. Journal of Education and Practice. (Online). 5(19): 56-65, (www.iiste.org), diakses tanggal 6 November 2016.

Rahayu, S., Widodo, AT., Sudarmin. 2013. Pengembangan Perangkat Pembelajaran Model

POE Berbantuan Media "I Am A Scientist". Journal of Curriculum and Educational Technology. (Online). 2 (1): 129 - 133,

(http://journal.unnes.ac.id/sju/index.php/ujet), diakses tanggal 10 Maret 2017.

Şeşen, B.A., Mutlu, A. 2016. Predict-Observe-Explain Tasks in Chemistry Laboratory: PreService Elementary Teachers' Understanding and Attitudes. Journal of Education. (Online), 6(2): 184-207. (http://dx.doi.org/10.19126/suje.46187), diakses tanggal 6 November 2016.

Sugiyono. 2013. Metode Penelitian Pendidikan Pendekatan Kuantitatif, Kualitatif, dan R\&D. Bandung: Alfabeta.

Suleman, F., Sihaloho, M., Alio, L. 2015. Pengaruh Strategi Pembelajaran dengan Teknik Poe terhadap Hasil Belajar Konsep Larutan Elektrolit dan Nonelektrolit 
Siswa di Kelas X SMA Negeri 1 Kabila. Jurnal Pendidikan Kimia. (Online). 3(1). (kim.ung.ac.id), diakses tanggal 6 November 2016.

Suparti. 2016. Metode Penelitian Pengembangan Inovasi Pembelajaran Beserta Contoh Proposal. Malang: Universitas Negeri Malang.

Tirtarahardja, U., Sulo, L. 2005. Pengantar Pendidikan. Jakarta: Adi Mahasatya.

Warsono., Hariyanto. 2016. Pembelajaran Aktif. Bandung: PT Remaja Rosdakarya Offset.

Widyaningrum, R., Sarwanto., Puguh. 2014. Pengembangan Modul Berorientasi Poe (Predict, Observe, Explain) pada Materi Pencemaran untuk Meningkatkan Hasil

Belajar Siswa. Jurnal Inkuiri. (Online). 3(2): 97-106, (http://jurnal.fkip.uns.ac.id/index.php/sains), diakses tanggal 6 November 2016. 